\title{
AN EVALUATION OF FINANCIAL PERFORMANCE OF MUNICIPAL CORPORATIONS IN KARNATAKA WITH REFERENCE TO MYSURU AND MANGALURU CITY CORPORATIONS
}

\author{
Mahesha. N M. \\ Research Schooler and Assistant Professor of Commerce, Government College for Women \\ (Autonomous) Mandya. Email: nmmgcwm@gmail.com

\section{Dr. K. Nagendrababu} \\ Professor, Department of Studies in Commerce, University of Mysore, Manasagangotri, \\ Mysuru. Email: nagendrababu280@gmail.com
}

\begin{abstract}
The research study attempts to evaluate the financial performance of Mysuru and Mangaluru City Corporations in Karnataka. The study is based on secondary data, which will be collected through secondary sources of financial statements of Mysuru and Mangaluru city corporation. The data so collected will be tabulated appropriately to achieve the objectives set. Required statistical tools will also be used to test the hypotheses formulated in the study. The per capita income and per capita expenditure were increased in all selected Municipal corporations during the study period 2010-11 to 2019-20. There is no significant difference in per capita income between Mysuru CC and Mangaluru CC, which means per capita income is almost equal in selected Municipal Corporations. The per capita expenditure is also equivalent to Mysuru CC and Mangaluru CC. It also found that the expenditure of selected Municipal Corporation is high compared to their income, which means the selected Municipal Corporation depends on State Government grants and loans. There is a significant difference between the development and non-development expenditure on revenue account of both Mysuru and Mangaluru City Corporations. The Mysuru CC had the highest development expenditure in 2017-18 and became 262.64 crores and lowest by 50.04 crores of Mangaluru CC in 2012-13. The Mysuru CC has the highest non-development expenditure in 2019-20 and became 199.52 crores and lowest by 16.73 crores of Mangaluru CC in 2010-11.
\end{abstract}

Keywords: Urban Local Bodies, Per Capita Income, Per Capita Expenditure, Development, and Non-Development Expenditure, Total Income, and Total Expenditure.

\section{Introduction:}

Urbanization is a truly global phenomenon. It is expected that urbanization will continue to be rapid, and the anti-migration policies will not have a measurable effect on urban population growth. For the rest of this century, the urban population growth rate in developing countries is projected to be about 3.5 percent, some three times the rural growth rate (Ravikanth Joshi, 2021). Urbanization is a trend unique to the past few decades. By 2050 it's projected that two- 
thirds of the world population will live in urban areas (more than 7 billion people) (World Bank report, 2017). The share of India's urban population has risen steadily during the past few decades. As per World Bank, India, along with China, Indonesia, Nigeria, and the United States, will lead the world's urban population by 2050. Mumbai witnessed large-scale ruralurban migration in the 20th century. Mumbai, in 2020, accommodates 22.9 million people and is the largest metropolis by population in India, followed by Delhi with 29 million inhabitants. Rapid urbanization has challenged the Urban Local Bodies (ULBs) or Municipal Corporations (MCs) and fails to fulfill citizens' expectations.

Moreover, the unplanned physical and industrial growth of towns and migration of people from rural to urban jurisdiction in search of better jobs, education, business, service, etc., have strained Municipal Corporations. Therefore, providing civic amenities like underground drainage, drinking water, road, transportation, market, power supply, solid waste management, stormwater drainage, park, etc., is very difficult for Municipal Corporations. Local SelfGovernment Institutions or Local Bodies directly influence the welfare of the people by providing civic, social, and economic infrastructure services and facilities in both urban and rural areas (P. K. Mohanty et al.). The finances of Urban Local Bodies (ULBs) have been assuming much more significant importance, with the urban areas increasingly becoming important in terms of population share and economic wealth (Ramakrishna Nallathiga, 2008). Municipal finance management is a crucial element of municipal management. It enables the local government to plan, mobilize, and use financial resources efficiently and effectively and fulfill its obligation to be accountable to its citizens (R K Venkateswaran, 2009).

Many developing countries are in the midst of a paradigm shift on generating resources to increase the delivery of municipal services such as drinking water, sanitation, roads, and schools (Charles J. Billand, 2006). In the case of Urban Local Bodies in India, the 74th Amendment to the Constitution of India, 1992, identified enormous responsibilities for the urban local governments. Besides the 18 items listed as municipal responsibilities in the Twelfth Schedule of the Constitution, the Legislature of a State, by law, can assign any tasks relating to:

1. The preparation of plans for economic development and social justice; and

2. The implementation of schemes as may be entrusted to them.

For strengthening the finances of urban local governments, two positive features were provided in the 74th Amendments to the Constitution:

(a) Provision for the constitution of State Finance Commissions (SFCs) every five years and

(b) Amendment of Article 280 of the Indian Constitution by inserting section 3(C), which requires the Central Finance Commission (CFC) to suggest measures needed to augment the consolidated fund of the states to supplement the resources of municipalities devolved based on the respective SFC recommendations (Siddaram and Bharadi, 2017). However, the progress in implementing SFC recommendations in several states has not been very encouraging. The $\mathrm{CFC}$ has also grappled in making recommendations of resource transfer to local governments in states. 
In India, the Municipal corporation is a local government body that administers a population of 3,00,000 or more. According to the Census of India, 2011, there are 210 municipal corporations in India in 26 states and 5 municipal corporations in 2 union territories. The Government of Karnataka has reconstituted the municipalities according to the 74th Constitutional Amendment Act. The towns have now been classified based on the population and other criteria as Town Panchayat (Population 10,000 to 20,000), Town Municipal Councils (Population 20,000 to 50,000), City Municipal Councils (Population 50,000 to 3,00,000), and City Corporations (Population 3.0 lakhs and above). Accordingly, there are 10 City Corporations (Except BBMP), 59 City Municipal Councils, 116 Town Municipal Councils, and 97 Town Panchayats in the state. To discharge the Obligatory and Discretionary functions notified in the Act, Municipal corporations have been vested with the powers to levy certain taxes and fees. Despite this, the State Government also transfers a portion of its general revenues to the urban local bodies. The primary sources of income for the Municipal corporations are derived from (a) taxes on building and lands, (b) user charge for water supply, (c) license fee for regulating the building construction activities and fee from other trade licenses, (d) taxes on advertisement, (e) duty on certain transfers of property, etc. The Municipal corporations can also raise loans from Central and State Governments and other Financial Institutions to meet the expenditures under capital heads of accounts.

\section{Review of literature:}

Isher Judge Ahluwalia (2019) Examined that planned urbanization is crucial for the sustainability of rapid growth and improving the quality of life of the 430 million people living in Indian cities and towns. Though investing in urban infrastructure to bridge the infrastructure investment deficit and upgrading its quality is very important, the analysis suggests that institutional reforms are crucial both for reaching out to the private sector for sharing the financing burden of infrastructure and for ensuring that the expansion of infrastructure results in improved service delivery. He argued that State governments are proactive in coming forth with necessary legislative reforms, the institutional framework for financial and regulatory support, financial devolution, and helping build capacity at the urban local government level. The impact can be seen in significant improvement in service delivery.

Dsouza and Arabi (2018) Research study has been conducted on "The Effect of Fiscal Decentralisation on the Expenditure of Urban Local Bodies: An Econometric Evidence from Mangalore City Corporation-India" and investigated the effect of fiscal decentralization on the expenditure (payments, capital payments, and total expenditure) of Mangalore City Corporation from 1987-2015 using the OLS regression technique. The study found fiscal decentralization to have a statistically significant effect on payments, capital payments, and total expenditure of Mangalore City Corporation. Policymakers in India need to implement the factors that enhance fiscal decentralization and economic growth to boost expenditure towards curbing the various challenges that confront ULBs.

Bhattacharyya, Anupam Dey, et al. (2017) view that a significant portion of the grant is usually sent at the end of the year, leaving little scope for utilization. Therefore, there is a need 
to use a developed e-governance process for timely remittance of grants and related information. Political intervention in decisions making process of the elected body should be avoided to restrict fund diversion and making unfruitful revenue expenditure often found in engaging casual labours or undertaking illegitimate repairing work as these minimize the available amount for infrastructure development.

Hundekar and Makandar's (2016) Research study has been conducted on 'evaluating the financial efficiency of selected city municipal corporations in Karnataka' and believe there is a need to integrate spatial planning at all levels: National, state, and cities. The integrated financial planning of sustainable urban infrastructure, improving the urban sectors and slum areas, state, and central government grants are required for cities at different stages in their development.

Sonal Nena(2014) compared total revenue income, total revenue expenditure, total capital income, and total capital expenditure of 6 Municipal Corporations', i.e., Ahmadabad, Vadodara, Bhavnagar, Jamnagar, Rajkot, and Surat Gujarat, for the period of 1996-97 to 200506 and suggested that this entire municipal corporation should follow \& maintain uniform accounting practices, more efforts, controlling measures, efficiency \& transparency while preparing budgets and prepared uniform formats of budgets \& uniform classification of different heads of revenues \& Capitals.

Mehta Ketan J. (2013), in his research, works entitled "A Comparative Study on Public Expenditure and Income of Rajkot Municipal Corporation," examined economic and social work of Rajkot Municipal Corporation during 2007-08 to 2011- 12 and found that revenue income, revenue expenditure, capital income, and capital expenditure are increased. But in comparison between income and expenditure, expenditure is $1.91 \%$ higher to income.

BRIJ Pal (2012) The financial requirements for bridging the existing gaps and meeting the increasing demand for essential services are significant. But there is hardly any awareness and sensitivity towards the financial dimensions involved in providing and managing even the minimum essential level of services. The net result is the deprivation of a substantial proportion of the urban population from core urban services such as water supply, sanitation, primary health, street lighting, primary education, etc. This has led to a marked deterioration in urban residents' standard and quality of life.

Serageldin, M. et al. (2008) described the wide range of difficulties in financing urban development and the response of the authorities to the challenges of a significant shift in the economic base resulting from falling trade barriers and globalization of the economy and focused on the challenges faced, local financial management and performance, partnership to address pressing urban issues and emerging trends in the financing of capital investment. This study also discussed the emergence of several significant new trends: the broadening of locally generated revenue sources, strengthening local financial management, and growing reliance on the partnership to finance capital investment. 


\section{Methodology}

\subsection{Objectives of the Research Study:}

1. To study the relationship in Per Capita Income between Mysuru and Mangaluru City Corporations.

2. To study the per capita expenditure relationship between Mysuru and Mangaluru City Corporations.

3. To analyze trends and differences between the Development and Non- Development Expenditure on Revenue account of the Mysuru and Mangaluru City Corporations.

\subsection{Testing of Hypotheses:}

\section{Hypotheses 1.}

$\mathrm{H}_{01}$ : There is no significant difference in Per Capita Income between Mysuru and Mangaluru City Corporations.

$\mathrm{H}_{\mathrm{a} 1}$ : There is a significant difference in Per Capita Income between Mysuru and Mangaluru City Corporations

\section{Hypotheses 2.}

$\mathrm{H}_{02}$ : There is no significant difference in Per Capita Expenditure between Mysuru and Mangalore City Corporations

$\mathrm{H}_{\mathrm{a} 2}$ : There is a significant difference in Per Capita Expenditure between Mysuru and Mangalore City Corporations

\section{Hypotheses 3.}

$\mathrm{H}_{03}$ : There is no significant difference between the Development and Non- Development Expenditure on Revenue account of the Mysuru and Mangaluru City Corporations $\mathrm{H}_{\mathrm{a} 3}$ : There is a significant difference between the Development and Non- Development Expenditure on Revenue account of the Mysuru and Mangaluru City Corporations

\subsection{Scope of the Research Study:}

This research study is confined to Mysuru and Mangaluru City Corporations and concentrates only on financial aspects. It is an attempt to study the financial performance of municipal corporations in Karnataka regarding Mysuru and Mangaluru city corporations. The operations of the Mysuru and Mangaluru City Corporations will be reviewed for a period of 10 years from 2010-11 to 2019-20.

\subsection{Sources of data:}

To examine the financial performance of the Mysuru and Mangaluru City Corporations, a quantitative research method will be used. Secondary data will be collected on Revenue Receipts, Revenue expenditures, Development Expenditure, Non-development Expenditure, Capital Receipts, and Capital Expenditure. Data will be from the published and unpublished sources such as government records, financial statements \& budget copies of Mysuru and Mangaluru City Corporations, municipal audit reports, books, journals, periodicals, etc. Statistical tools such as average growth rate, Averages, SD, percentages, ANOVA have been 
used. The per capita income and per capita expense are used for comparison and tested by ANOVA.

Table-1: Revenue and Capital Receipts of the Mysuru and Mangaluru City Corporations (Rs in Crores)

\begin{tabular}{|c|c|c|c|c|c|c|}
\hline \multirow[t]{2}{*}{ Year } & \multicolumn{3}{|c|}{ Total Receipts of the Mysuru CC } & \multicolumn{3}{|c|}{ Total Receipts of the Mangaluru CC } \\
\hline & $\begin{array}{ll}\text { Total Revenue } \\
\text { Receipts }\end{array}$ & $\begin{array}{l}\text { Total Capital } \\
\text { Receipts }\end{array}$ & $\begin{array}{l}\text { Total } \\
\text { Receipts }\end{array}$ & $\begin{array}{l}\text { Total } \\
\text { Revenue } \\
\text { Receipts }\end{array}$ & $\begin{array}{l}\text { Total Capital } \\
\text { Receipts }\end{array}$ & $\begin{array}{l}\text { Total } \\
\text { Receipts }\end{array}$ \\
\hline $\begin{array}{l}2010- \\
11\end{array}$ & $\begin{array}{l}195.79 \\
(76.13)\end{array}$ & $\begin{array}{l}61.37 \\
(23.86)\end{array}$ & $\begin{array}{l}257.16 \\
(100)\end{array}$ & $\begin{array}{l}115.87 \\
(78.23)\end{array}$ & $\begin{array}{l}32.24 \\
(21.76)\end{array}$ & $\begin{array}{l}148.11 \\
(100)\end{array}$ \\
\hline $\begin{array}{l}2011- \\
12\end{array}$ & $\begin{array}{l}232.02 \\
(67.51)\end{array}$ & $\begin{array}{l}111.63 \\
(32.48)\end{array}$ & $\begin{array}{l}343.65 \\
(100)\end{array}$ & $\begin{array}{l}146.43 \\
(78.99)\end{array}$ & $\begin{array}{l}38.93 \\
(21.00)\end{array}$ & $\begin{array}{l}185.36 \\
(100)\end{array}$ \\
\hline $\begin{array}{l}2012- \\
13\end{array}$ & $\begin{array}{l}246.67 \\
(74.28)\end{array}$ & $\begin{array}{l}85.40 \\
(25.71)\end{array}$ & $\begin{array}{l}332.07 \\
(100)\end{array}$ & $\begin{array}{l}175.11 \\
(77.66)\end{array}$ & $\begin{array}{l}50.36 \\
(22.33)\end{array}$ & $\begin{array}{l}225.47 \\
(100)\end{array}$ \\
\hline $\begin{array}{l}2013- \\
14\end{array}$ & $\begin{array}{l}279.42 \\
(74.56)\end{array}$ & $\begin{array}{l}95.29 \\
(25.43)\end{array}$ & $\begin{array}{l}374.71 \\
(100)\end{array}$ & $\begin{array}{l}177.16 \\
(79.86)\end{array}$ & $\begin{array}{l}44.66 \\
(20.13)\end{array}$ & $\begin{array}{l}221.82 \\
(100)\end{array}$ \\
\hline $\begin{array}{l}2014- \\
15\end{array}$ & $\begin{array}{l}300.44 \\
(77.21)\end{array}$ & $\begin{array}{l}88.64 \\
(22.78)\end{array}$ & $\begin{array}{l}389.08 \\
(100)\end{array}$ & $\begin{array}{l}143.49 \\
(71.85)\end{array}$ & $\begin{array}{l}56.20 \\
(28.14)\end{array}$ & $\begin{array}{l}199.69 \\
(100)\end{array}$ \\
\hline $\begin{array}{l}2015- \\
16\end{array}$ & $\begin{array}{l}393.17 \\
(75.59)\end{array}$ & $\begin{array}{l}126.94 \\
(24.40)\end{array}$ & $\begin{array}{l}520.11 \\
(100)\end{array}$ & $\begin{array}{l}230.02 \\
(82.56)\end{array}$ & $\begin{array}{l}48.57 \\
(17.43)\end{array}$ & $\begin{array}{l}278.59 \\
(100)\end{array}$ \\
\hline $\begin{array}{l}2016- \\
17\end{array}$ & $\begin{array}{l}421.75 \\
(79.42)\end{array}$ & $\begin{array}{l}109.24 \\
(20.57)\end{array}$ & $\begin{array}{l}530.99 \\
(100)\end{array}$ & $\begin{array}{l}178.87 \\
(75.65)\end{array}$ & $\begin{array}{l}57.56 \\
(24.34)\end{array}$ & $\begin{array}{l}236.43 \\
(100)\end{array}$ \\
\hline $\begin{array}{l}2017- \\
18\end{array}$ & $\begin{array}{l}436.44 \\
(75.57)\end{array}$ & $\begin{array}{l}141.03 \\
(24.42)\end{array}$ & $\begin{array}{l}577.47 \\
(100)\end{array}$ & $\begin{array}{l}234.35 \\
(72.17)\end{array}$ & $\begin{array}{l}90.36 \\
(27.82)\end{array}$ & $\begin{array}{c}324.71 \\
(100)\end{array}$ \\
\hline $\begin{array}{l}2018- \\
19\end{array}$ & $\begin{array}{l}440.02 \\
(75.53)\end{array}$ & $\begin{array}{l}142.50 \\
(24.46)\end{array}$ & $\begin{array}{l}582.52 \\
(100)\end{array}$ & $\begin{array}{l}221.88 \\
(81.99)\end{array}$ & $\begin{array}{l}48.72 \\
(18.00)\end{array}$ & $\begin{array}{l}270.60 \\
(100)\end{array}$ \\
\hline $\begin{array}{l}2019- \\
20\end{array}$ & $\begin{array}{l}409.51 \\
(69.39)\end{array}$ & $\begin{array}{l}180.58 \\
(30.60)\end{array}$ & $\begin{array}{l}590.09 \\
(100)\end{array}$ & $\begin{array}{l}254.69 \\
(77.90)\end{array}$ & $\begin{array}{l}72.24 \\
(22.09)\end{array}$ & $\begin{array}{l}326.93 \\
(100)\end{array}$ \\
\hline
\end{tabular}

Source: Financial statements of Mysuru and Mangalore City Corporations (Figures in bracket indicate the percentage) 
Table 2: Expenditure of the Mysuru and Mangaluru City Corporations (Rs. In Crores)

\begin{tabular}{|c|c|c|c|c|c|c|}
\hline \multirow[t]{2}{*}{ Year } & \multicolumn{3}{|c|}{ Total Expenditure of Mysuru CC } & \multicolumn{3}{|c|}{ Total Expenditure of Mangaluru CC } \\
\hline & $\begin{array}{l}\text { Revenue } \\
\text { Expenditure } \\
\end{array}$ & $\begin{array}{l}\text { Capital } \\
\text { Expenditure }\end{array}$ & $\begin{array}{l}\text { Total } \\
\text { Expenditure }\end{array}$ & $\begin{array}{l}\text { Revenue } \\
\text { Expenditure } \\
\end{array}$ & $\begin{array}{l}\text { Capital } \\
\text { Expenditure }\end{array}$ & $\begin{array}{l}\text { Total } \\
\text { Expenditure } \\
\end{array}$ \\
\hline $\begin{array}{r}2010- \\
11\end{array}$ & $\begin{array}{l}173.85 \\
(64.42)\end{array}$ & $\begin{array}{r}95.99 \\
(35.57)\end{array}$ & $\begin{array}{r}269.84 \\
(100)\end{array}$ & $\begin{array}{r}76.10 \\
(62.66)\end{array}$ & $\begin{array}{r}45.34 \\
(37.33)\end{array}$ & $269.84(100)$ \\
\hline $\begin{array}{r}2011- \\
12\end{array}$ & $\begin{array}{l}146.67 \\
(60.06)\end{array}$ & $\begin{array}{r}97.52 \\
(39.93)\end{array}$ & $\begin{array}{r}244.19 \\
(100)\end{array}$ & $\begin{array}{r}87.71 \\
(68.37)\end{array}$ & $\begin{array}{r}40.56 \\
(31.62)\end{array}$ & $244.19(100)$ \\
\hline $\begin{array}{r}2012- \\
13\end{array}$ & $\begin{array}{r}163.76 \\
(59.19)\end{array}$ & $\begin{array}{r}112.90 \\
(40.80)\end{array}$ & $\begin{array}{r}276.66 \\
(100) \\
\end{array}$ & $\begin{array}{r}76.99 \\
(52.64)\end{array}$ & $\begin{array}{r}69.24 \\
(47.35)\end{array}$ & $276.66(100)$ \\
\hline $\begin{array}{r}2013- \\
14\end{array}$ & $\begin{array}{l}212.85 \\
(66.78)\end{array}$ & $\begin{array}{c}105.88 \\
(33.21)\end{array}$ & $\begin{array}{r}318.73 \\
(100)\end{array}$ & $\begin{array}{r}96.55 \\
(56.98)\end{array}$ & $\begin{array}{r}72.89 \\
(43.01)\end{array}$ & $318.73(100)$ \\
\hline $\begin{array}{r}2014- \\
15\end{array}$ & $\begin{array}{l}232.62 \\
(71.28)\end{array}$ & $\begin{array}{r}93.71 \\
(28.18)\end{array}$ & $\begin{array}{r}326.33 \\
(100)\end{array}$ & $\begin{array}{r}94.75 \\
(60.13)\end{array}$ & $\begin{array}{r}62.82 \\
(39.86)\end{array}$ & $326.33(100)$ \\
\hline $\begin{array}{r}2015- \\
16\end{array}$ & $\begin{array}{l}290.97 \\
(66.06)\end{array}$ & $\begin{array}{l}149.46 \\
(33.93)\end{array}$ & $\begin{array}{r}440.43 \\
(100)\end{array}$ & $\begin{array}{l}132.50 \\
(59.48)\end{array}$ & $\begin{array}{r}90.25 \\
(40.51)\end{array}$ & $440.43(100)$ \\
\hline $\begin{array}{r}2016- \\
17\end{array}$ & $\begin{array}{l}280.82 \\
(71.81)\end{array}$ & $\begin{array}{c}110.19 \\
(28.18)\end{array}$ & $\begin{array}{r}391.01 \\
(100)\end{array}$ & $\begin{array}{c}140.94 \\
(58.40)\end{array}$ & $\begin{array}{l}100.38 \\
(41.59)\end{array}$ & $391.01(100)$ \\
\hline $\begin{array}{r}2017- \\
18\end{array}$ & $\begin{array}{l}383.18 \\
(62.19)\end{array}$ & $\begin{array}{l}232.90 \\
(37.80)\end{array}$ & $\begin{array}{r}616.08 \\
(100)\end{array}$ & $\begin{array}{l}169.13 \\
(51.82)\end{array}$ & $\begin{array}{l}157.24 \\
(48.17)\end{array}$ & $616.08(100)$ \\
\hline $\begin{array}{r}2018- \\
19\end{array}$ & $\begin{array}{l}314.56 \\
(62.76)\end{array}$ & $\begin{array}{l}186.63 \\
(37.23)\end{array}$ & $\begin{array}{r}501.19 \\
(100)\end{array}$ & $\begin{array}{l}165.25 \\
(55.15)\end{array}$ & $\begin{array}{l}134.35 \\
(44.84)\end{array}$ & $501.19(100)$ \\
\hline $\begin{array}{r}2019- \\
20\end{array}$ & $\begin{array}{l}400.94 \\
(73.25)\end{array}$ & $\begin{array}{l}146.35 \\
(26.74)\end{array}$ & $\begin{array}{r}547.29 \\
(100)\end{array}$ & $\begin{array}{l}139.41 \\
(60.66)\end{array}$ & $\begin{array}{r}90.41 \\
(39.33)\end{array}$ & $547.29(100)$ \\
\hline
\end{tabular}

Source: Financial statements of Mysuru and Mangalore City Corporations (Figures in bracket indicate the percentage)

\section{Hypothesis-1:}

$\mathrm{H}_{01}$ : There is no significant difference in Per Capita Income between Mysuru and Mangaluru City Corporations. 
Table 3: Per capita Income of the Mysuru and Mangaluru city corporations (Rs. in crores)

\begin{tabular}{|c|c|c|c|c|c|c|c|c|}
\hline \multirow[t]{2}{*}{ Year } & \multicolumn{4}{|c|}{ Per Capita Income of Mysuru } & \multicolumn{4}{|c|}{ Per Capita Income of Mangaluru } \\
\hline & $\begin{array}{l}\text { Projecte } \\
\text { d } \\
\text { Populati } \\
\text { on }\end{array}$ & $\begin{array}{l}\text { Total } \\
\text { Income } \\
@\end{array}$ & $\begin{array}{l}\text { Per } \\
\text { Capita } \\
\text { Income }\end{array}$ & 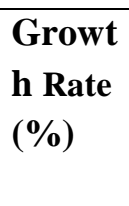 & $\begin{array}{l}\text { Projected } \\
\text { Population }\end{array}$ & $\begin{array}{l}\text { Total } \\
\text { Income } \\
@\end{array}$ & $\begin{array}{l}\text { Per } \\
\text { Capita } \\
\text { Income }\end{array}$ & $\begin{array}{l}\text { Growt } \\
\text { h Rate } \\
(\%)\end{array}$ \\
\hline $\begin{array}{l}2010- \\
11\end{array}$ & $9,77,000$ & 257.16 & 2632 & --- & $6,18,000$ & 148.11 & 2396 & -- \\
\hline $\begin{array}{l}2011- \\
12\end{array}$ & $9,98,000$ & 343.65 & 3443 & 30.81 & $6,27,000$ & 185.36 & 2956 & 23.37 \\
\hline $\begin{array}{l}2012- \\
13\end{array}$ & $\begin{array}{l}10,20,00 \\
0\end{array}$ & 332.07 & 3255 & -5.46 & $6,36,000$ & 225.47 & 3545 & 19.92 \\
\hline $\begin{array}{l}2013- \\
14\end{array}$ & $\begin{array}{l}10,42,00 \\
0\end{array}$ & 374.71 & 3596 & 10.47 & $6,45,000$ & 221.82 & 3439 & -2.99 \\
\hline $\begin{array}{l}2014- \\
15\end{array}$ & $\begin{array}{l}10,65,00 \\
0\end{array}$ & 389.08 & 3653 & 1.58 & $6,55,000$ & 199.69 & 3048 & -11.36 \\
\hline $\begin{array}{l}2015- \\
16\end{array}$ & $\begin{array}{l}10,89,00 \\
0\end{array}$ & 520.11 & 4776 & 30.74 & $6,64,000$ & 278.59 & 4195 & 37.63 \\
\hline $\begin{array}{l}2016- \\
17\end{array}$ & $\begin{array}{l}11,12,00 \\
0\end{array}$ & 530.99 & 4775 & -0.02 & $6,74,000$ & 236.43 & 3507 & -16.40 \\
\hline $\begin{array}{l}2017- \\
18\end{array}$ & $\begin{array}{l}11,37,00 \\
0\end{array}$ & 577.47 & 5078 & 6.34 & $6,84,000$ & 324.71 & 4747 & 35.35 \\
\hline $\begin{array}{l}2018- \\
19\end{array}$ & $\begin{array}{l}11,62,00 \\
0\end{array}$ & 582.52 & 5013 & -1.28 & $6,94,000$ & 270.60 & 3899 & -17.86 \\
\hline $\begin{array}{l}2019- \\
20\end{array}$ & $\begin{array}{l}11,85,00 \\
0\end{array}$ & 590.09 & 4979 & -0.67 & $7,03,000$ & 326.93 & 4650 & 19.26 \\
\hline $\begin{array}{l}\text { Averag } \\
\text { e }\end{array}$ & & & 4120 & & & & 3638.2 & \\
\hline S. D & & & 896.02 & & & & 749.34 & \\
\hline F. cal. & \multicolumn{8}{|c|}{1.7013} \\
\hline F. crit & \multicolumn{8}{|c|}{4.4138} \\
\hline P value & \multicolumn{8}{|c|}{0.208} \\
\hline $\mathrm{H}_{01}$ & \multicolumn{8}{|c|}{ Accepted } \\
\hline
\end{tabular}

Source: Financial statements of Mysuru and Mangalore City Corporations (Figures in bracket indicate the percentage)

The ANOVA technique was used to measure the significant difference in per capita Income between Mysuru and Mangaluru City Corporation. Table 3 portrays the Mysuru and Mangaluru city corporations (Rs. in crores) from 2010-11 to 2019-20. In Mysuru CC, the per capita income was 2632 rupees in 2010-11, and it was 2396 rupees in Mangaluru CC for the same year. During the study period, 2010-11 to 2019-20, the per capita income was continuously 
increased in Mysuru CC with fluctuated growth rate. But the per capita income was reduced by $5.46 \%$ in 2012-13 and became 3255 rupees in Mysuru CC, and again reduced in 2016-17, $2018-19$, and $2019-20$ by $0.02 \%, 1.28 \%$, and $0.67 \%$, respectively. The per capita income of Mangaluru CC was increased during the study period 2010-11 to 2019-20 except the years 2013-14, 2014-15, 2016-17, and 2018-19. During the study period, 2010-11 to 2019-20, the per capita income of Mysuru CC was highest compared to Mangaluru CC. In Mysuru CC, the highest per capita income was 5078 rupees in 2017-18. In Mangaluru CC, the highest per capita income was 4747 rupees in $2017=18$. The calculated value of $F(1.7013)$ is less than the table value (4.4138), and the $\mathrm{p}$ value (0.208) is more than 0.05 . Hence null hypothesis is accepted, which means there is no significant difference in Per Capita Income between Mysuru and Mangaluru City Corporations.

\section{Hypothesis-2:}

$\mathrm{H}_{02}$ : There is no significant difference in Per Capita Expenditure between Mysuru and Mangaluru City Corporations

Table 4: Per capita expenditure of the Mysuru and Mangaluru city corporations (Rs. in crores)

\begin{tabular}{|c|c|c|c|c|c|c|c|c|}
\hline \multirow[t]{2}{*}{ Year } & \multicolumn{4}{|c|}{ Per Capita Expenditure of the Mysuru CC } & \multicolumn{4}{|c|}{ Per Capita Expenditure of the Mangaluru CC } \\
\hline & $\begin{array}{l}\text { Projecte } \\
\text { d } \\
\text { Populati } \\
\text { on }\end{array}$ & $\begin{array}{l}\text { Total } \\
\text { Expendit } \\
\text { ure @ }\end{array}$ & \begin{tabular}{|l|} 
Per \\
Capita \\
Expendit \\
ure \\
\end{tabular} & $\begin{array}{l}\text { Growt } \\
\text { h Rate } \\
(\%)\end{array}$ & $\begin{array}{l}\text { Projected } \\
\text { Population }\end{array}$ & $\begin{array}{l}\text { Total } \\
\text { Expendit } \\
\text { ure @ }\end{array}$ & $\begin{array}{l}\text { Per } \\
\text { Capita } \\
\text { Expendi } \\
\text { ture }\end{array}$ & $\begin{array}{l}\text { Grow } \\
\text { th } \\
\text { Rate } \\
(\%)\end{array}$ \\
\hline $\begin{array}{l}2010- \\
11\end{array}$ & $\begin{array}{r}9,77,00 \\
0\end{array}$ & 269.84 & 2762 & $\begin{array}{l}---- \\
\end{array}$ & $6,18,000$ & 121.44 & 1970 & $\begin{array}{c}--- \\
\end{array}$ \\
\hline $\begin{array}{l}2011- \\
12\end{array}$ & $\begin{array}{r}9,98,00 \\
0\end{array}$ & 244.19 & 2447 & -11.40 & $6,27,000$ & 128.27 & 2050 & 4.06 \\
\hline $\begin{array}{l}2012- \\
13\end{array}$ & $\begin{array}{r}10,20,0 \\
00\end{array}$ & 276.66 & 2712 & 10.82 & $6,36,000$ & 146.23 & 2300 & 12.19 \\
\hline $\begin{array}{l}2013- \\
14\end{array}$ & $\begin{array}{r}10,42,0 \\
00\end{array}$ & 318.73 & 3059 & 12.79 & $6,45,000$ & 169.44 & 2630 & 14.13 \\
\hline $\begin{array}{l}2014- \\
15\end{array}$ & $\begin{array}{r}10,65,0 \\
00\end{array}$ & 326.33 & 3064 & 0.01 & $6,55,000$ & 157.57 & 2410 & -8.36 \\
\hline $\begin{array}{l}2015- \\
16\end{array}$ & $\begin{array}{r}10,89,0 \\
00\end{array}$ & 440.43 & 4044 & 31.98 & $6,64,000$ & 222.75 & 3346 & 38.83 \\
\hline $\begin{array}{l}2016- \\
17\end{array}$ & $\begin{array}{r}11,12,0 \\
00\end{array}$ & 391.01 & 3516 & -13.05 & $6,74,000$ & 241.32 & 3580 & 6.99 \\
\hline $\begin{array}{l}2017- \\
18\end{array}$ & $\begin{array}{r}11,37,0 \\
00 \\
\end{array}$ & 616.08 & 5418 & 54.09 & $6,84,000$ & 326.37 & 4770 & 33.24 \\
\hline $\begin{array}{l}2018- \\
19\end{array}$ & $\begin{array}{r}11,62,0 \\
00\end{array}$ & 501.19 & 4313 & -20.39 & $6,94,000$ & 299.6 & 4320 & -9.43 \\
\hline $\begin{array}{l}2019- \\
20\end{array}$ & $\begin{array}{r}11,85,0 \\
00\end{array}$ & 547.29 & 4618 & 7.07 & $7,03,000$ & 229.82 & 3270 & 24.30 \\
\hline $\begin{array}{l}\text { Averag } \\
\mathrm{e}\end{array}$ & & & 3595.3 & & & & 3064.6 & \\
\hline
\end{tabular}






Source: Financial statements of Mysuru and Mangalore City Corporations (Figures in bracket indicate the percentage)

Table 4 portrays the Mysuru and Mangaluru city corporations (Rs. in crores) from 2010-11 to 2019-20. The ANOVA technique was used to measure the difference in per capita expenditure between Mysuru and Mangaluru City Corporations. The per capita expense was 2762 rupees in 2010-11 in Mysuru C C. In the same year; it was 1970 rupees in Mangaluru C. C. In 201718 , the per capita expense increased with a high growth rate by $54.09 \%$ in Mysuru C C. and became 5418 rupees. It was increased by $33.24 \%$ in Mangaluru CC. In all selected Municipal Corporations, the per capita income was increased overall. In the last two years, 2018-19 and 2019-20, the per capita expense of Mysuru C C was reduced by $20.39 \%$ and $7.07 \%$ and became 4313 rupees \& 4618 Rupees respectively, whereas it was decreased by $9.43 \%$ and $24.30 \%$ in Mangaluru C C in the same year. In Mysuru CC, the highest per capita expense was 5418 rupees, and the lowest per capita expense was 2447 rupees. In Mangaluru C C, the highest per capita expense was 4770 rupees, and the lowest per capita expense was 1970 rupees. The calculated value of $F(1.5128)$ is less than the table value (4.4138), and the p-value (0.2345) is more than 0.05; hence null hypothesis is accepted, which means there is no significant difference in Per Capita Expenditure between Mysuru and Mangaluru City Corporations.

Table 5: Development and non-development expenditure on revenue account of the Mysuru City Corporation (Rs. in Crores)

\begin{tabular}{|c|c|c|c|c|c|c|c|c|}
\hline \multirow[t]{3}{*}{ Year } & \multirow{2}{*}{\multicolumn{2}{|c|}{$\begin{array}{l}\text { Development } \\
\text { Expenditure }\end{array}$}} & \multirow{3}{*}{$\begin{array}{l}\text { Total } \\
\text { Develop } \\
\text { ment } \\
\text { Expendit } \\
\text { ure }\end{array}$} & \multicolumn{3}{|c|}{ Non-Development Expenditure } & \multirow{3}{*}{$\begin{array}{l}\text { Total Non - } \\
\text { Developmen } \\
\mathrm{t} \\
\text { Expenditure }\end{array}$} & \multirow{3}{*}{$\begin{array}{l}\text { Total } \\
\text { Revenue } \\
\text { Expenditur } \\
\text { e }\end{array}$} \\
\hline & & & & \multirow{2}{*}{$\begin{array}{l}\text { Establishm } \\
\text { ent } \\
\text { Expenses }\end{array}$} & \multirow{2}{*}{$\begin{array}{l}\text { Administr } \\
\text { ative } \\
\text { Expenses }\end{array}$} & \multirow{2}{*}{$\begin{array}{l}\text { Interest } \\
\& \text { Finance } \\
\text { Charges }\end{array}$} & & \\
\hline & $\begin{array}{l}\text { O\&M } \\
\text { Expense } \\
\mathrm{s}\end{array}$ & $\begin{array}{l}\text { Programm } \\
\mathrm{e} \\
\text { Expenses }\end{array}$ & & & & & & \\
\hline $\begin{array}{c}2010 \\
-11\end{array}$ & 92.83 & 12.31 & $\begin{array}{l}105.14 \\
(60.47)\end{array}$ & 37.72 & 9.13 & 21.86 & $\begin{array}{c}68.71 \\
(39.53)\end{array}$ & $\begin{array}{c}173.85 \\
(100)\end{array}$ \\
\hline $\begin{array}{c}2011 \\
-12\end{array}$ & 75.47 & 10.36 & $\begin{array}{c}85.83 \\
(58.51)\end{array}$ & 39.18 & 5.31 & 16.35 & $\begin{array}{c}60.84 \\
(31.49)\end{array}$ & $\begin{array}{c}146.67 \\
(100)\end{array}$ \\
\hline $\begin{array}{c}2012 \\
-13\end{array}$ & 93.90 & 14.64 & $\begin{array}{l}108.54 \\
(66.27)\end{array}$ & 44.32 & 10.86 & 0.04 & $\begin{array}{c}55.22 \\
(33.73)\end{array}$ & $\begin{array}{c}163.76 \\
(100)\end{array}$ \\
\hline $\begin{array}{c}2013 \\
-14\end{array}$ & 113.11 & 18.92 & $\begin{array}{l}129.03 \\
(60.62)\end{array}$ & 58.64 & 7.67 & 17.51 & $\begin{array}{c}83.82 \\
(39.38)\end{array}$ & $\begin{array}{c}212.85 \\
(100)\end{array}$ \\
\hline
\end{tabular}




\begin{tabular}{|c|c|c|c|c|c|c|c|c|}
\hline $\begin{array}{c}2014 \\
-15\end{array}$ & 126.60 & 15.19 & $\begin{array}{c}141.79 \\
(60.95)\end{array}$ & 62.92 & 8.86 & 19.05 & $\begin{array}{c}90.83 \\
(39.05)\end{array}$ & $\begin{array}{c}232.62 \\
(100)\end{array}$ \\
\hline $\begin{array}{c}2015 \\
-16\end{array}$ & 209.53 & 9.72 & $\begin{array}{c}219.25 \\
(75.35)\end{array}$ & 61.19 & 10.51 & 0.02 & $\begin{array}{c}71.72 \\
(24.65)\end{array}$ & $\begin{array}{c}290.97 \\
(100)\end{array}$ \\
\hline $\begin{array}{c}2016 \\
-17\end{array}$ & 171.53 & 6.61 & $\begin{array}{c}178.14 \\
(63.43)\end{array}$ & 63.10 & 10.73 & 28.85 & 102.68 & $\begin{array}{c}280.82 \\
(100)\end{array}$ \\
\hline $\begin{array}{c}2017 \\
-18\end{array}$ & 226.53 & 36.11 & $\begin{array}{c}262.64 \\
(68.54)\end{array}$ & 71.20 & 17.00 & 32.34 & $\begin{array}{c}120.54 \\
(31.45)\end{array}$ & $\begin{array}{c}383.18 \\
(100)\end{array}$ \\
\hline $\begin{array}{c}2018 \\
-19\end{array}$ & 194.66 & 5.58 & 200.24 & 74.99 & 11.29 & 28.04 & $\begin{array}{c}114.32 \\
(36.35)\end{array}$ & $\begin{array}{c}314.56 \\
(100)\end{array}$ \\
\hline $\begin{array}{c}2019 \\
-20\end{array}$ & 200.09 & 1.33 & 201.42 & 81.81 & 88.45 & 29.26 & 199.52 & $\begin{array}{c}400.94 \\
(100)\end{array}$ \\
\hline
\end{tabular}

Source: Audited financial statements of Mysuru and Mangalore City Corporations (Figures in bracket indicates the percentage)

Table 6: Development and Non-Development Expenditure on Revenue Account of the Mangaluru City Corporation (Rs. in Crores)

\begin{tabular}{|c|c|c|c|c|c|c|c|c|}
\hline \multirow[t]{3}{*}{ Year } & \multirow{2}{*}{\multicolumn{2}{|c|}{$\begin{array}{l}\text { Development } \\
\text { Expenditure }\end{array}$}} & \multirow{3}{*}{$\begin{array}{l}\text { Total } \\
\text { Develop } \\
\text { ment } \\
\text { Expendit } \\
\text { ure }\end{array}$} & \multicolumn{3}{|c|}{ Non-Development Expenditure } & \multirow{3}{*}{$\begin{array}{l}\text { Total Non- } \\
\text { Developmen } \\
\mathrm{t} \\
\text { Expenditure }\end{array}$} & \multirow{3}{*}{$\begin{array}{l}\text { Total } \\
\text { Revenue } \\
\text { Expenditure }\end{array}$} \\
\hline & & & & \multirow{2}{*}{$\begin{array}{l}\text { Establishm } \\
\text { ent } \\
\text { Expenses }\end{array}$} & \multirow{2}{*}{$\begin{array}{l}\text { Administra } \\
\text { tive } \\
\text { Expenses }\end{array}$} & \multirow{2}{*}{$\begin{array}{l}\text { Interest } \\
\& \text { Financ } \\
\text { e } \\
\text { Charges }\end{array}$} & & \\
\hline & $\begin{array}{l}\text { O\&M } \\
\text { Expense } \\
\mathrm{s}\end{array}$ & $\begin{array}{l}\text { Programm } \\
\mathrm{e} \\
\text { Expenses }\end{array}$ & & & & & & \\
\hline $\begin{array}{c}2010- \\
11\end{array}$ & 57.93 & 1.44 & $\begin{array}{c}59.37 \\
(78.01)\end{array}$ & 13.67 & 3.01 & 0.05 & $\begin{array}{c}16.73 \\
(21.98)\end{array}$ & $\begin{array}{l}76.10 \\
(100)\end{array}$ \\
\hline $\begin{array}{c}2011- \\
12\end{array}$ & 65.14 & 2.66 & $\begin{array}{c}67.80 \\
(77.30)\end{array}$ & 16.60 & 3.06 & 0.25 & $\begin{array}{c}19.91 \\
(22.69)\end{array}$ & $\begin{array}{l}87.71 \\
(100)\end{array}$ \\
\hline $\begin{array}{c}2012- \\
13\end{array}$ & 46.46 & 3.58 & $\begin{array}{c}50.04 \\
(64.99)\end{array}$ & 20.21 & 3.02 & 3.72 & $\begin{array}{c}26.95 \\
(35.00)\end{array}$ & $\begin{array}{l}76.99 \\
(100)\end{array}$ \\
\hline $\begin{array}{c}2013- \\
14\end{array}$ & 70.52 & 2.86 & $\begin{array}{c}73.38 \\
(76.00)\end{array}$ & 19.84 & 2.59 & 0.74 & $\begin{array}{c}23.17 \\
(23.99)\end{array}$ & $\begin{array}{l}96.55 \\
(100)\end{array}$ \\
\hline $\begin{array}{c}2014- \\
15\end{array}$ & 65.77 & 1.99 & $\begin{array}{c}67.76 \\
(71.51)\end{array}$ & 22.93 & 2.92 & 1.14 & $\begin{array}{c}26.99 \\
(28.48)\end{array}$ & $\begin{array}{l}94.75 \\
(100)\end{array}$ \\
\hline $\begin{array}{c}2015- \\
16\end{array}$ & 100.80 & 2.60 & $\begin{array}{c}103.4 \\
(78.03)\end{array}$ & 22.27 & 4.32 & 2.51 & $\begin{array}{c}29.10 \\
(21.96)\end{array}$ & $\begin{array}{c}132.50 \\
(100\end{array}$ \\
\hline $\begin{array}{c}2016- \\
17\end{array}$ & 107.17 & 3.39 & $\begin{array}{l}110.56 \\
(78.44)\end{array}$ & 22.98 & 4.53 & 2.87 & $\begin{array}{c}30.38 \\
(21.55)\end{array}$ & $\begin{array}{c}140.94 \\
(100)\end{array}$ \\
\hline $\begin{array}{c}2017- \\
18\end{array}$ & 136.40 & 3.52 & $\begin{array}{l}139.92 \\
(82.72)\end{array}$ & 22.95 & 4.91 & 1.35 & $\begin{array}{c}29.21 \\
(17.27)\end{array}$ & $\begin{array}{c}169.13 \\
(100)\end{array}$ \\
\hline $\begin{array}{c}2018- \\
19\end{array}$ & 126.49 & 4.97 & $\begin{array}{l}131.46 \\
(79.55)\end{array}$ & 27.51 & 5.21 & 1.07 & $\begin{array}{c}33.70 \\
(20.39)\end{array}$ & $\begin{array}{c}165.25 \\
(100)\end{array}$ \\
\hline $\begin{array}{c}2019- \\
20\end{array}$ & 100.71 & 6.00 & $\begin{array}{l}106.71 \\
(76.54)\end{array}$ & 28.33 & 3.33 & 1.04 & $\begin{array}{c}32.70 \\
(23.45)\end{array}$ & $\begin{array}{c}139.41 \\
(100)\end{array}$ \\
\hline
\end{tabular}

Source: Audited financial statements of Mysuru and Mangalore City Corporations (Figures in bracket indicates the percentage) 


\section{Hypotheses 3.}

H03: There is no significant difference between the Development and Non- Development Expenditure on Revenue account of the Mysuru and Mangaluru City Corporations

Table -7: ANOVA technique was used in Development and Non -Development Expenditure on Revenue Account from 2010-11 To 2019-20

\begin{tabular}{|c|c|c|c|c|c|c|}
\hline \multirow[t]{2}{*}{ year } & \multicolumn{3}{|c|}{ Mysuru City Corporation } & \multicolumn{3}{|c|}{ Mangaluru City Corporation } \\
\hline & $\begin{array}{l}\text { Development } \\
\text { Expenditure }\end{array}$ & $\begin{array}{l}\text { Non- } \\
\text { Development } \\
\text { Expenditure }\end{array}$ & $\begin{array}{l}\text { Total } \\
\text { Revenue } \\
\text { Expenditure }\end{array}$ & $\begin{array}{l}\text { Development } \\
\text { Expenditure }\end{array}$ & $\begin{array}{l}\text { Non- } \\
\text { Development } \\
\text { Expenditure }\end{array}$ & $\begin{array}{l}\text { Total } \\
\text { Revenue } \\
\text { Expenditure }\end{array}$ \\
\hline $2010-11$ & $\begin{array}{l}105.14 \\
(60.47)\end{array}$ & $\begin{array}{r}68.71 \\
(39.53)\end{array}$ & $\begin{array}{r}173.85 \\
(100)\end{array}$ & $\begin{array}{r}59.37 \\
(78.01)\end{array}$ & $\begin{array}{r}16.73 \\
(21.98)\end{array}$ & $\begin{array}{l}76.10 \\
(100)\end{array}$ \\
\hline 2011-12 & $\begin{array}{r}85.83 \\
(58.51)\end{array}$ & $\begin{array}{r}60.84 \\
(31.49)\end{array}$ & $\begin{array}{r}146.67 \\
(100)\end{array}$ & $\begin{array}{r}67.80 \\
(77.30)\end{array}$ & $\begin{array}{r}19.91 \\
(22.69)\end{array}$ & $\begin{array}{l}87.71 \\
(100)\end{array}$ \\
\hline $2012-13$ & $\begin{array}{l}108.54 \\
(66.27)\end{array}$ & $\begin{array}{r}55.22 \\
(33.73)\end{array}$ & $\begin{array}{r}163.76 \\
(100)\end{array}$ & $\begin{array}{r}50.04 \\
(64.99)\end{array}$ & $\begin{array}{r}26.95 \\
(35.00)\end{array}$ & $\begin{array}{l}76.99 \\
(100)\end{array}$ \\
\hline $2013-14$ & $\begin{array}{l}129.03 \\
(60.62)\end{array}$ & $\begin{array}{r}83.82 \\
(39.38)\end{array}$ & $\begin{array}{r}212.85 \\
(100)\end{array}$ & $\begin{array}{r}73.38 \\
(76.00)\end{array}$ & $\begin{array}{r}23.17 \\
(23.99)\end{array}$ & $\begin{array}{l}96.55 \\
(100)\end{array}$ \\
\hline $2014-15$ & $\begin{array}{l}141.79 \\
(60.95)\end{array}$ & $\begin{array}{r}90.83 \\
(39.05)\end{array}$ & $\begin{array}{r}232.62 \\
(100)\end{array}$ & $\begin{array}{r}67.76 \\
(71.51)\end{array}$ & $\begin{array}{r}26.99 \\
(28.48)\end{array}$ & $\begin{array}{l}94.75 \\
(100)\end{array}$ \\
\hline $2015-16$ & $\begin{array}{l}219.25 \\
(75.35)\end{array}$ & $\begin{array}{r}71.72 \\
(24.65)\end{array}$ & $\begin{array}{r}290.97 \\
(100)\end{array}$ & $\begin{array}{r}103.4 \\
(78.03)\end{array}$ & $\begin{array}{r}29.10 \\
(21.96)\end{array}$ & $\begin{array}{r}132.50 \\
(100\end{array}$ \\
\hline $2016=17$ & $\begin{array}{l}178.14 \\
(63.43)\end{array}$ & $\begin{array}{l}102.68 \\
(36.57)\end{array}$ & $\begin{array}{r}280.82 \\
(100)\end{array}$ & $\begin{array}{l}110.56 \\
(78.44)\end{array}$ & $\begin{array}{r}30.38 \\
(21.55)\end{array}$ & $\begin{array}{r}140.94 \\
(100)\end{array}$ \\
\hline $2017-18$ & $\begin{array}{l}262.64 \\
(68.54)\end{array}$ & $\begin{array}{l}120.54 \\
(31.45)\end{array}$ & $\begin{array}{r}383.18 \\
(100)\end{array}$ & $\begin{array}{l}139.92 \\
(82.72)\end{array}$ & $\begin{array}{r}29.21 \\
(17.27)\end{array}$ & $\begin{array}{r}169.13 \\
(100)\end{array}$ \\
\hline $2018-19$ & $\begin{array}{l}200.24 \\
(63.65)\end{array}$ & $\begin{array}{l}114.32 \\
(36.35)\end{array}$ & $\begin{array}{r}314.56 \\
(100)\end{array}$ & $\begin{array}{l}131.46 \\
(79.55)\end{array}$ & $\begin{array}{r}33.70 \\
(20.39)\end{array}$ & $\begin{array}{r}165.25 \\
(100)\end{array}$ \\
\hline $2019-20$ & $\begin{array}{l}201.42 \\
(50.23)\end{array}$ & $\begin{array}{l}199.52 \\
(49.77)\end{array}$ & $\begin{array}{r}400.94 \\
(100)\end{array}$ & $\begin{array}{l}106.71 \\
(76.54)\end{array}$ & $\begin{array}{r}32.70 \\
(23.45)\end{array}$ & $\begin{array}{r}139.41 \\
(100)\end{array}$ \\
\hline Sum & 1632.02 & 968.20 & 2600.22 & 910,40 & 286.84 & 1179.24 \\
\hline Average & 163.20 & 96.82 & 260.02 & 91.04 & 26.88 & 117.92 \\
\hline Variance & 3339.62 & 1788.96 & 7989.69 & 986.70 & 29.81 & 1265.41 \\
\hline F. cal. & & 15.4042 & & & 28,7629 & \\
\hline F. crit. & & 3.3541 & & & 3.3541 & \\
\hline $\mathrm{P}$ value & & 3.44 & & & 2.04 & \\
\hline $\begin{array}{l}\text { Hypothesis } \\
\mathbf{H}_{03}\end{array}$ & & Rejected & & & Rejected & \\
\hline
\end{tabular}

Source: Audited financial statements of Mysuru and Mangalore City Corporations (Figures in bracket indicates percentage)

Table 7 portrays the difference between the Development and Non- Development Expenditure on Revenue account of the Mysuru and Mangaluru City Corporations (Rs. in crores) from 2010-11 to 2019-20. The ANOVA model was used to measure the difference between the development and non-development expenditure on revenue account of Mysuru and Mangalore City Corporations. In Mysuru CC, Development \& Non- Development expenditure for 2010- 
11 was 105.14 crores and 68.71 crores, respectively. In the same year, it was $59.37 \& 16.73$ crores in Mangaluru CC, respectively. During the study period, 2010-11 to 2019-20, the Development \& Non- Development expenditure was continuously increased in Mysuru CC with fluctuated growth rate. The Development Expenditure of Mysuru CC was decreased by 85.83, 178.14, and 200.24 crores in 2011-12, 2016-17, and 2018-19 respectively. Similarly Non- The development expenditure of Mysuru CC was decreased by 60.84, 55.22, 114.32 crores in 2011-12, 2012-13, and 2015-16 respectively. The Development \& Non- Development expenditure of Mangaluru CC was increased during the study period 2010-11 to 2019-20 except the years 2012-13, 2014-15, and 2019-20. The Mysuru CC had the highest development expenditure in 2017-18 and became 262.64 crores and lowest by 50.04 crores of Mangaluru $\mathrm{CC}$ in 2012-13. The Mysuru CC has the highest non-development expenditure in 2019-20 and became 199.52 crores and lowest by 16.73 crores of Mangaluru CC in 2010-11. In both Mysuru $\mathrm{CC}$ and Mangaluru CC, the calculated value of $\mathrm{F}$ is more than the table value and p-value also more than 0.05; hence null hypothesis is rejected, and the alternative hypothesis is accepted, which means there is a significant difference between the Development and Non- Development Expenditure on Revenue account of the Mysuru and Mangaluru City Corporations

\section{Conclusion:}

From the analysis, we conclude that overall, the per capita income and per capita expenditure were increased in all selected Municipal corporations during the study period 2010-11 to 201920. There is no significant difference in per capita income between Mysuru CC and Mangaluru $\mathrm{CC}$, which means per capita income is almost equal in selected Municipal corporations. The per capita expenditure is also equal in Mysuru CC and Mangaluru CC. It also found that the expenditure of selected Municipal Corporation is high compared to their income, which means the selected Municipal Corporation depends on State Government grants and loans. There is a significant difference between the development and non -development expenditure on revenue account of both Mysuru and Mangalore City Corporations. Mysuru CC had the highest development expenditure in 2017-18 and became 262.64 crores and lowest by 50.04 crores of Mangaluru CC in 2012-13. The Mysuru CC has the highest non-development expenditure in 2019-20 and became 199.52 crores and lowest by 16.73 crores of Mangaluru CC in 2010-11.

\section{References:}

1. Isher Judge Ahluwalia (2019), "Urban Governance in India," Journal of Urban Affairs, 41:1, 83-102, DOI: $10.1080 / 07352166.2016 .1271614$.

2. Vincent Vinod Dsouza, Arabi. U (2018), "The Effect of Fiscal Decentralisation on the Expenditure of Urban Local Bodies: An Econometric Evidence from Mangalore City Corporation-India," Innovative Journal of Business and Management, IJBM, Vol. 7, Issue 07, Pp No: 151-156.

3. Smriti Ranjan Bhattacharyya, Anupam Dey and Gautam Bandyopadhyay (2017), "urban local self-government in India: infrastructure development and performance analysis," International Refereed Research Journal, vol.- viii, issue - 2, April 2017.

4. S G Hundekar and N M Makandar (2016), "Evaluating the financial efficiency of selected city municipal corporations in Karnataka." Research Journal of Commerce and Behavioural science, IJRP, ISSN 22511547, Vol.06, No. 2, pp20-29.

5. Shubhagato Dasgupta \& Ramesh Ramanathan (2016), "Estimates of Urban Infrastructure Financing Requirements in India 2006-2031," Working Papers id:8237, e Social Sciences. 
6. mysurucity.mrc.gov.in and mangalurucity.mrc.gov.in

7. Sonal N., (2014). An Empirical Study on Financial Performance of Corporations of Gujarat State. International Journal of Advanced Research in Computer Science and Management Studies, 2(1), 1826.

8. Census of India 2011 retrieved from https://en.wikipedia.org/wiki/List_of_municipal _corporations_in_India

9. Serageldin, M., et al.; (2008). Municipal Financing and Urban Development. Human Settlements Global Dialogue Series, 3, United Nations Human Settlement Programme, UN-Habitat, Nairobi

10. Bandyopadhyay, (2011). Finances of Urban Local Bodies in Jharkhand: Soma Issues and Comparisons. International Studies Program Working Paper 11-13, Andrew Young School of Policy Studies, Georgia State University, Atlanta, USA.

11. Ravikath Joshi, (2021), From Accounting to Accountability: Building the Case for Municipal Accounting Reform

12. R K Venkateswaran, (2009), “finance municipal” directeur de publication. New Delhi. 